\title{
COMPARATIVE ANALYSIS OF SUCCESS IN HIGHER EDUCATION IN UKRAINE AND THE USA
}

\author{
Olena Kozmenko \\ Ph.D., Associate Professor, Volodymyr Dahl East Ukrainian National University, Ukraine \\ e-mail: olena_kozmenko@ukr.net,orcid.org/0000-0002-7063-2324 \\ Andrzej Kryński \\ Professor, Ph.D., Polonia University in Czestochowa, Interdisciplinary Faculty, Poland \\ e-mail: a.krynski@ap.edu.pl, orcid.org/0000-0001-9635-023X
}

\section{Summary}

The article is devoted to the study of the success in the system of higher education in the USA and Ukraine. This concept in higher education has interested scholars in recent decades and has caused many debates about determining student progress. At the end of the twentieth century in the United States, student achievement was measured by quantitative indicators that demonstrated the effectiveness of higher education. But the gradual change in the higher education priorities, the characteristics of the students, the need to improve the educational process has led to a revision of the definition of this phenomenon and provoked a number of studies to expand this concept, creating models of success. The modern definition of student success in US higher education establishments involves academic success and the development of the necessary personality traits, skills and abilities for further self-realization. Ukrainian researchers consider success as a category of pedagogical psychology, as this concept concerns, first of all, the personal development of the student, the skills and abilities of useful interaction. At the same time, a number of studies made by Ukrainian educators are devoted to the issue of academic success, which is also considered as a qualitative development of the student's personality. Unfortunately, compared to the United States, Ukraine does not have sufficient data on the quality of higher education, there are no experimental studies of success models for students. There is a lack of information on further self-realization of students, their employment. Thus comparing student success in the two countries, it can be concluded that there is a difference in understanding of this concept by American and Ukrainian scholars, the issue of retention, persistence and graduation is not sufficiently developed by Ukrainian educators. The problem to find the ways to improve higher education is common, but its development, as well as the creation of models for achieving success is not sufficiently represented in Ukrainian scientific discourses.

Keywords: definitions, postsecondary education, a review of student success frameworks, student development, academic achievement, educational process in Ukraine

DOI: https://doi.org/10.23856/4211

\section{Introduction}

It is well known that there is a clear relation between higher education and success because the process of education contributes to many aspects of success, for example, forms the ability of students to rule their own lives (competence in life and time management), 
helps to grow the abilities and opportunities (personal growth), set and achieve goals (purpose in life). Perhaps people with a developed level of such characteristics can show strong persistence in the higher education process, so in this way, success can determine the achievement of the goals of higher education. Both interpretations can be plausible, suggesting that higher education and success are interrelated. However, it seems that the predominant direction of influence is the first, which means that education contributes to the important achievement of individual skills and self-realization. The experience gained in higher education establishment can provide the access to greater income and opportunities, but also probably can develop the skills and strategies which are necessary to overcome difficulties and obstacles in the life of a student (Ryff, 2018). So the main purpose of Ukrainian higher education is to form highly educated people with developed cultural and spiritual needs, diverse knowledge. According to H. Shevchenko, a famous Ukrainian scientist, «it is very important to bring up students with the high level of value consciousness and the critical thinking ability who would eager to develop their unique individuality, strive for the highest aspirations» (Shevchenko, 2017). Such qualities are very important for any person because they help to achieve success. But the definition of success is still the subject of scientific discussions and among scholars, educators, policymakers, employers, students themselves there are different points of view. The main task of the article is to present different ideas and describe the definitions of student success in American and Ukrainian higher education systems, compare them, and define the main problems in this field.

\section{Defining Student Success in the USA}

In the XXI century, the interest in this problem arose with the new force, especially in the USA, where a lot of efforts were made to define student success and develop student success frameworks in higher education. For a long time, student success was «defined using traditional measures of academic achievements, such as scores on standardized college entry exams, college grades, and credit hours earned in consecutive terms, which represent progress toward the degree» (Kuh et al. 2006:5). This approach narrows the term of students' success in higher education only to indicate academic performance correlated with the average score (GPA), completion rating, and other similar measurable indicators of success. Perhaps it is used to show the effectiveness of universities and colleges in measurable indicators like clear evidence of student learning process and for decades measuring other more complex or abstract dimensions of student success can be a more difficult task for plenty of institutions. J. Hearn (2006) noted that one of the challenges in measuring other aspects of success may be the difficulty of identifying indicators that should be «understandable, measurable, cost-effective, and reflect key policy challenges» (Hearn, 2006).

In 2016, Jillian Kinzie and George Kuh made a review of student success frameworks for the Lumina Foundation, in which they proposed the different definitions of «success» «depending on who uses the term for what purposes with what audiences» (Kinzie \& Kuh, 2016:10). According to their review, each of the stakeholders has its meaning for student success. Researchers noted that the term «success» is often used to refer to the efforts that higher education institutions can make to help students achieve their learning aspirations. This is often manifested in the expansion of access to education for certain socially disadvantaged groups of students (development of certain educational programs, adaptation or preparatory courses, providing some additional services). Another definition of student success is used as a conclusion about the individual or group level of achievements. From the perspective of state and federal 
politicians, student success typically means access to low-cost higher education, short-term study, a degree, employment, and post-university earnings. For colleges and universities student success can mean «first-year student retention, student persistence to completion, content knowledge gains, engagement in educational processes that foster a high-quality undergraduate experience, and even students` success» (Kinzie \& Kuh, 2016). Other definitions of student success relate to the organization of greater inclusiveness and the achievement of equal rights of students or increasing the level of academic readiness for higher education. These definitions give us the broad perspectives of the «student success» study. In 2006 it was defined «as academic achievement, engagement in educationally purposeful activities, satisfaction, acquisition of desired knowledge, skills and competencies, persistence, attainment of educational objectives, and post-college performance» (Kuh et al. 2006:7). Ten years later the given definition was «student success is broadly defined as increased numbers of diverse student groups participating in high-quality educational experiences, earning high-quality credentials (degrees, certifications, certificates)» (Kinzie \& Kuh, 2016:3). As we can see some new aspects appear in the latter definition and the influence of many factors including some characteristics of students become very popular in academic discourse. Modern concerns about unequal access to higher education, different learning conditions, and growing research on the ethnic, gender, and cultural diversity of the student population have provided new grounds for reconsidering the basis for identifying and enriching different dimensions of success (Kinzie \& Kuh, 2017). In this way, it can be demonstrated, that student success consists of various elements. From this point of view, higher education should provide an experience of positive transformational change for the young person, and should not be a limited process focused only on increasing the quantitative results of testing or examination. Researchers emphasize the importance of a clear distinguishing between short-term learning outcomes - assessments and long-term educational outcomes personal and professional achievements (Kim et al., 2010). Recent research on the perspectives of goals, challenges, and needs of college students revealed the fact that students had a complex understanding of success, which included at least two different dimensions: academic achievement and personal development (Wolff-Eisenberg \& Braddlee, 2018). The problems that the study participants suffered in college influenced the formation of their learning experience and prospects for success. Most challenges arose mainly at the intersection of their academic and personal lives - work, education, finance, childcare, language problems, transport, and the use of resources and services. While some students with families and jobs tried to balance house choirs and college, others reported having problems with English language use (reading, writing, and/or speaking). Moreover, some students found it was difficult to get to college by public transport, given the additional costs and unreliability of transportation, while others were frustrated by the inability to use the necessary resources of the campus. So, it is clear that students have different priorities, try to find the necessary time and opportunities, review the goals. All this should be taken into account defining the success because «student success is not just the enrolment and transition of students from course to course, it is, above all, redesigning institutions to support students in the complex interaction of their life experiences» (Higher Learning Commission, 2018:2). It is obvious to recognize that higher education should take into account all the different aspects of student development to identify an expanded set of indicators which include the diversity of elements vital to students` overall success. Frankly speaking about the definition of student success it is necessary to admit that it is a multidimensional concept that includes different and equally important student outcomes, suggesting that higher education should not be focused solely on knowledge, but should also develop personality and form different useful skills. A more detailed analysis of modern concepts of student success in the USA, 
their trends and peculiarities were given in our previous articles (Kozmenko, 2019; Kozmenko, 2019; Kozmenko, 2020). The importance of a holistic approach to student success that includes both personal and educational goals is emphasized by modern tendencies of US higher education (Cuseo, 2007). According to this approach, the most important trend in promoting student success is its definition in terms of positive student outcomes (a sense of personal significance, self-efficacy, determination, active learning process involvement, reflective thinking, social integration, self-awareness). Only a combination of these indicators should stimulate students to succeed (Cuseo, 2007). But in examining student success, American educators recognize the presence of barriers for students to succeed. Among them is the change in the characteristics of the «traditional» student, the high transfer of students among institutions, a significant extension of the terms of higher education, a low percentage of graduation. «Half of the students who begin college never finish» was said by American president Obama. (Obama, 2009, February 24). In 2012 the American Association of Community Colleges proclaimed that «Fewer than half $(46 \%)$ of students who enter community colleges intending to earn a degree or certificate have attained that goal, transferred to a baccalaureate institution, or are still enrolled 6 years later» (AACC, 2012, April:9). In 2020 according to the National Center for Education Statistics «At 2-year degree-granting institutions overall, 33 percent of first-time, full-time undergraduate students who began seeking a certificate or associate's degree in fall 2015 attained it within 150 percent of the normal time required for completion of these programs (an example of completing a credential within 150 percent of the normal time is completing a 2-year degree within 3 years). Besides, $<\ldots>15$ percent of students had transferred to another institution, 11 percent remained enrolled in their first institution, and 41 percent were no longer enrolled in their first institution and had not been reported as a transfer at a different institution» (Undergraduate Retention and Graduation Rates, April 2020). Many efforts are done to overcome these problems and the development, implementation, and evaluation of policies about student success framework will help a lot. The main conclusions about student success were introduced by Perna \& Thomas (2006). They proposed 6 main ideas to better understand the complexity of difficulties. According to them «1) student success is a longitudinal process; 2) multiple theoretical approaches inform understanding of student success; 3) student success is shaped by multiple levels of context [individual student, family, school, and social, economic and policy contexts]; 4) the relative contribution of different disciplinary perspectives [education, psychology, sociology, and economics], to understanding student success varies; 5) multiple methodological approaches contribute to the knowledge of student success; and 6) student success processes vary across groups» (Perna \& Thomas, 2006:26). Thus this framework can contribute to the development of a common understanding of student success in the USA. Using such principles in other countries, especially in Ukraine, provides clear perspectives of this problem. "The framework offers a guide to the development, implementation, and evaluation of student success policies and practices, and encourages policymakers, practitioners, and researchers to view student success interventions as part of a broader and longitudinal process» (Kinzie \& Kuh, 2017:7).

\section{Main ideas of Ukrainian authors about success}

In our state, the problem of student success is based on employing theories and research from sociology, economics, psychology, education, philosophy, and others. Like American scientists our scholars demonstrate different points of view at this concept, regarding it as an «academic achievement», «life effectiveness», «personal development» etc. In this article, we 
will discuss the main ideas of Ukrainian authors. Having considered student success by many approaches, the role of higher education is appreciated very much. During the educational process, a person with critical thinking skills, culture, and the ability to innovate can be up brought. It may influence the development of both the successful personal future and state prosperity. Different socio-cultural conditions dictate a different understanding of success, however, the changes taking place in Ukrainian society in recent years, as well as modern globalization processes necessitate the development of a certain system of criteria that determines success regardless of social conditions. It is not a top-secret that the modern understanding of student success in Ukraine is influenced by Western traditions and values. This fact is proved by several linguistic researchers. For example, the work of Kaslova \& Chernova (2010) about the cultural-linguistic interpretation of success gives the analysis of the concept of «success». The conclusion was made about the success core in the English language picture of the world are concepts such as «result, happy outcome»; «accomplishment, attainment»; «fame, being known». This term in everyday life is associated with a high position in something; a lot of money; respect; efforts; admiration; and many other definitions: aim, purpose, wealth, social status, luck, something that people like, effect, work in a satisfactory way, to intend, prosperity, advance, succession. The concept of «success» has almost the same understanding in our language picture: the achievement of the desired, the purpose; social recognition (approval, attention, reputation, glory); luck (Kaslova \& Chernova, 2010). In the Ukrainian language, the concept of success is regarded in two senses. The first is defined as a positive consequence of work, business; significant achievements, the second means public recognition, approval of something, someone's achievements. Success usually is considered in a certain type of activity, which should be accompanied by the presence of certain successes, i.e. achievements, victories, etc.

So, the concept of understanding «success» in our and Western cultures is similar in certain aspects but also has its characteristics. The common features include the achievement of financial success, popularity, power, recognition of merit, and career growth by society, self-realization, and inner satisfaction. The distinguishing features involve the following: 1) - in Western culture, success is associated primarily with the achievement of financial independence, wealth, and career promotion. Whereas in Slavic culture, success is associated with victory in battle, with achievements in knowledge, winning sympathy; 2) the attitude of our people to those who are in need and less successful is sympathetical. Americans, on the other hand, if they do not despise, they do not show a drop of pity for the «losers». In their understanding, success depends entirely on the own efforts of the person, who must overcome possible difficulties and failures without expecting pity from anyone. Thus, Slavic culture is characterized by an understanding of success as a set of natural abilities and luck, which is not always measured by material factors. For Western culture, on the contrary, success is, above all, material goods, prosperity, financial stability, which is achieved through hard daily work (Goncharova, 2016).

Success as an essential component of human existence is the result of creative activity to recreate own «self», going beyond own life limitations, from natural determination and socio-cultural conditions. Success acts as a complex, multifaceted object of study. It is characterized by internal unity and contradictions. On one hand, success is a characteristic and indicator of the individual's experience of their actions and efforts, and on the other hand, it is an indicator of the originality of own position among other people (Kuritskaya, 2012). The innovative function of higher education is manifested in the renewal of social values and norms through the development of new and the use of progressive values from the world educational experience, adequate to the socio-historical conditions of Ukraine. So in Ukraine education 
must ensure not only the introduction of Western values and the development of global culture but also the preservation of the authentic values of our nation. «Eternal universal values can be a criterion for harmonizing these contradictory tendencies. The subject of reproduction of the cultural model of the unity of education and values in the conditions of globalization can be educated people in Ukraine» (Huberskyy \& Andrushchenko, 2008:166). Based on value orientations and ideals pedagogy it forms a specific program of educational activities that should prepare people for life in the context of existing realities, as well as in terms of a social ideal. So in Ukrainian pedagogical traditions success can be regarded as the result of well-thought-out, prepared tactics of the teacher, the family. Success contributes to the achievement of a person's state of life satisfaction, which, in turn, is a breeding ground for further action that promotes the goal of self-realization. This condition stimulates growth, which does not necessarily have to be associated with traditional activities but may relate to the emotional, moral, spiritual maturity of a person or the development of other aspects of his/her potential, which is also a success in life (Romanovskyy, 2011:4).

The guiding principle of the pedagogy of success is the humanistic orientation of the educational process. This principle involves the creation of pedagogical conditions aimed at the disclosure and development of the abilities of the learner, positive self-realization. It includes the formation of professional self-awareness, which means self-education, self-esteem, self-control, self-programming for success; the development and widespread use of self-concept aimed at awareness of own capabilities, self-development, and self-improvement; recognition of the authority of the teacher and the use of his/her psychological and pedagogical experience in the educational process; cooperation of the teacher and the student; creating real models of success situations that provide opportunities for students to express themselves, to experience a sense of joy of success, to believe in themselves, in their strength; the use of new pedagogical technologies and methods that contribute to the personal development of students and their self-improvement; formation of students' focus on successful professional activity; stimulating self-education and activation of independent work of students (Romanovskyy, 2011:6). So, as we can see student success in the Ukrainian higher education establishment is the development of personal characteristics and goals, self-improvement, but academic performance is also very important. The essence of student success is seen in the concept of efficiency, which can be explained as correlating the result of any process with the incurred costs of this process. Since the student's activity has a decisive influence on educational achievement the success of the educational activity is considered as a characteristic of educational activity reflecting the effectiveness of this activity, the ratio of the costs incurred by the student, and the result obtained.

The Ukrainian model of life success is now of great interest, as it has changed in recent years. According to Ukrainian scientist Yu. Ilyina «a specific feature of the Ukrainian formula of success is that we focus mainly on common goals, dreams and pay relatively little attention to how they can be achieved» (Ilyina, 2009:105). That's why our people often show the way of life when they underestimate ambitions, act cautiously, with limited initiative, copy someone`s model frequently, without considering their own decisions. They say to achieve success is to mean at the very beginning is to enhance requirements, set high goals, hard-reached horizons. But further in the process of the achievements due to different long checks, made mistakes and efforts the requirements and goals became reasonable and affordable. The peculiarity of the behavior of Ukrainians in achieving the chosen purposes is the rapid change of moods and attitudes towards themselves, their path to success, interest-only to own personality (Ilyina, 2009). The age of today's higher education students (18-25) is a sensitive period for learning and developing goals. In this period mental models impose their filters on the model of «success» 
which means that the success represented by 20 -year-olds is significantly different from the success model of 30, 40, 50-year-olds. At present time in Ukraine the external motivations of education, the social prestige of higher education are significantly modified. So the personality of the student is also subject to changes as we can see «the phenomenon of the devaluation of adulthood has formed, and, therefore, problems with personal responsibility and maturity» (Kocharyan et al., 2009:380). Ukrainian model of student success is different from the American one. It is influenced by the socio-historical environment of the country, economic factors, business models, government and educational policies, etc. That is why the meaning of success for students in Ukraine can depend on different factors and demonstrate personal preferences despite the common for the USA idea of the «American Dream». According to the main principles of Ukrainian higher education reform, «high quality higher education is a public good that provides vast opportunities for self-realization of all citizens, promotes their democratic worldview, cultivates the ability to think critically, be responsible and demanding, be ready to defend their rights and freedoms and state independence of Ukraine».

It means that the quality of education influences student success at the present stage of the transformation of society. The success of educational activities depends on the characteristics of all components of the educational process. Based on the concept of pedagogical systems of Nina Kuzmina was proposed the classification of the factors of the success of educational activities, depending on which structural component of the pedagogical system a particular factor belongs to (Kuznetsov, 2001). This classification of factors of success allows us to consider the pedagogical phenomenon and its influence on the effectiveness of education. The factors are considered as experimentally identified reasons that affect the effectiveness of this activity and relate to any structural component of the pedagogical system in which it takes place. The significance of various factors for student success is not the same and depends on the choice of success criteria. Academic performance is determined by the whole complex of success factors, therefore, the influence of an individual factor can not be determined in terms of points. The factors related to the characteristics of the motivational sphere of the individual and the level of intellectual development have a decisive influence on the level of student success. The latter include the ability of students to use different modes of mental work. In this regard, a means of increasing student success can be a purposeful impact on subjective (related to the students themselves) factors of motivational and intellectual nature (Sidorchuk, Dubasenyuk, 2002). Ukrainian educators for student success use the terms «academic performance», «learning success», «learning efficiency», «educational success», which although similar in meaning but are not identical. University progress reflects the degree of knowledge, skills, and abilities established according to the standards of higher education, in terms of their comprehension, completeness, depth, strength (Dyachenko \& Kandybovich, 1993)

Student success is not only a measure of cognitive activity in universities and colleges, which means the recorded level of knowledge and the degree of diligence. It is also important to consider the attitude of students to their specialty, their interests, and inclinations. The difference between «academic performance» and «student success» is obvious because the first term means training results and measures but the second one means the process and quality characteristics of studying. (Kocharyan et al., 2009). So the main criteria for student success and high-quality postsecondary education in Ukraine are quantitative indicators of the development of the higher education system in Ukraine; indicators that characterize the internal quality implementation of postsecondary education in higher education institutions; elements that characterize the external quality providing of higher education (Richnyy zvit Natsionalnoho ahentstva iz zabezpechennya yakosti vyshchoyi osvity za 2019 rik, 2020) The process of enhancing 
the quality of higher education in Ukraine has just started and studying of student success is not sufficient. There are not many pieces of research about the retention and completion of Ukrainian students. Comparing with the active work of US universities about the recording indicators of the number of enrolled and graduated students, Ukrainian universities do not have or do not show this information. The statistics about students' dropout is absent, but the numbers of a student entered in 2014 and graduated in 2018 is in 8,4 times lower (1 438000 enrolled students and 171000 of graduates). (Richnyy zvit Natsionalnoho ahentstva iz zabezpechennya yakosti vyshchoyi osvity za 2019 rik, 2020). Unfortunately, this situation does not give clear information about the effectiveness of Ukrainian higher education establishments. Also, it should be mentioned that the quality of graduates' training is difficult to evaluate «because in Ukraine there has been no systematic monitoring of employees Therefore, it is impossible to say what percentage of young people found a job in general and in their specialty in particular» (Richnyy zvit Natsionalnoho ahentstva iz zabezpechennya yakosti vyshchoyi osvity za 2019 rik, 2020:26). So the actual task for universities and other institutions to create a system for tracking the trajectory and success of further career growth of graduates of higher education institutions for adequate analysis of the quality of higher education.

\section{Conclusions}

Thus, the term «success» can have different meanings and definitions in the scientificpedagogical findings. In the terms of common understanding it means an activity that is accompanied by a certain emotional state, it is directed outward or inward and leads the subject to the desired result. This result is verified objectively or subjectively with the predictable or acceptable costs and for the desired period. For a long time within the American higher education system success is seen as measurable indicators of the effectiveness of institutions whereas Ukrainian educators considered it as part of different kinds of student development. The changes in societies caused the redetermination of this concept which leads to new perspectives in the field of US pedagogical and psychological research. In contrast in Ukraine only recently the attention to the student success problem was given and not much empirical data were obtained. Usually, in the training process, it is used and repeated a model of education activity leads to successful consequences. Ukrainian scholars directly link student success with the functioning of the intellect, the cognitive formations that provide individual «maps of the world» - mental models. The analysis also shows the need to combine multidisciplinary knowledge (from philosophy, medicine, sociology, pedagogy, and business models) with purely psychological achievements in the study of student success.

\section{References}

American Association of Community Colleges. (2012, April). Reclaiming the American dream: A report from the 21-century commission on the future of community colleges. Washington, DC: Author.

Cuseo J. (2007, July). The big picture. Esource for College Transitions. Retrieved from: https://sc.edu/nrc/system/pub_files/ES_4-6_Jul07.pdf

Dyachenko M.I., Kandybovich L.A. (1993) Psikhologiya vysshey shkoly: Ucheb. posob [Psychology of higher education: texrbook]. Mn.: Universitetskoye [in Ukrainian].

Ilyina Yu. M. (2009) Naukovyi ohlyad problematyky uspikhu ta uspishnosti [Scientific review of the problem of success and success]. Aktualni problemy psykholohiyi: Psykholohichna 
teoriya i tekhnolohiya navchannya. Kyiv: Vyd-vo NPU imeni M. P. Drahomanova. vol. 8, no. 6 [in Ukrainian].

Goncharova Ye. N. (2016) Kontsept uspekh/success v russkoy i amerikanskoy lingvokulturakh: istoriko-etimologicheskiy aspekt [The concept of success in Russian and American linguistic cultures: historical and etymological aspect]. Vestnik Adygeyskogo gosudarstvennogo universiteta. Seriya 2: Filologiya i iskusstvovedeniye. no. 2 (177) [in Russian].

Hearn J. C. (2006, October). Student success: What research suggests for policy and practice. Retrieved from: https://nces.ed.gov/npec/pdf/synth_Hearn.pdf

Higher Learning Commission (2018) Defining student success data: Recommendations for changing the conversation. Retrieved from: http://download.hlcommission.org/initiatives/StudentSuccess Conversation.pdf

Huberskyy L., Andrushchenko V. (2008) Filosofiya yak teoriya ta metodolohiya rozvytku osvity [Philosophy as a theory and methodology of educational development]. K.: "MP Lesya» [in Ukrainian].

Kaslova A.A, Chernova N.A. (2010) Kontseptsiya uspekha v russko-angloyazychnoy kartine mira [The concept of success in the Russian and English language picture of the world]. Political Linguistics (2) 32, 176-180 [in Russian].

Kim E., Newton F., Downey R., \& Benton S. (2010). Personal factors impacting college student success: Constructing college learning effectiveness inventory (CLEI). 44, 112-125.

Kinzie J. \& Kuh G. (2016) Review of student success frameworks to mobilize higher education. Retrieved from Center for Postsecondary Research website: http://cprindiana.edu/.

Kinzie J., \& Kuh G. (2017) Reframing student success in college: Advancing know-what and know-how. Change: The Magazine of Higher Learning, 49, 19-27. DOI:10.1080/00091383.20 17.1321429

Kuh G. D., J. L. Kinzie, J. A. Buckley, B. K. Bridges, and J. C. Hayek. (2006) What Matters to Student Success: A Review of the Literature Volume 8. Washington, DC: National Postsecondary Education Cooperative

Kocharyan A.S., Frolova Ye.V., Pavlenko V.N., Chichikhina N.A. (2009) Effektivnost uchebnoy deyatelnosti studentov: problema vybora faktorov uspeshnosti i misheney pedagogicheskogo vozdeystviya [The effectiveness of educational activities of students: the problem of choosing the factors of success and targets of pedagogical influence]. Problemi yempirichnikh doslidzhen u psikhologii. vol. 2 [in Russian].

Kozmenko O. (2019) Analiz vyznachennya uspikhu v systemi vyshchoyi osvity SSHA na pochatku XXI stolittya [Analysis of the definition of success in the system of higher education in the United States at the beginning of the XXI century]. Dukhovnist osobystosti: metodolohiya, teoriya i praktyka. Severodonetsk: vyd-vo SNU im. V. Dalya, vol. 5 (92), pp. 108-118. DOI: https://doi.org/10.33216/2220-6310-2019-92-5-108-118 [in Ukrainian].

Kozmenko O.I. (2019) Suchasni teoretychni pohlyady na uspikh studentiv [Modern theoretical views on student success]. Aktualni pytannya humanitarnykh nauk: mizhvuzivskyy zbirnyk naukovykh prats molodykh vchenykh Drohobytskoho derzhavnoho pedahohichnoho universytetu imeni Ivana Franka. Drohobych: Vydavnychyy dim "Helvetyka”. no. 23. vol. 2, pp. 123-127 [in Ukrainian].

Kozmenko O. (2020) Vyznachennya uspikhu studentiv: analiz terminiv [Definition of student success: analysis of terms]. Pedahohika formuvannya tvorchoyi osobystosti u vyshchiy i zahalnoosvitniy shkolakh. Zaporizhzhya: KPU, no. 68. vol. 1, pp. 73-77. DOI https://doi.org/10.328 40/1992-5786.2020.68-1.14 [in Ukrainian]. 
Kuritskaya Yu. V. (2012) Sotsialno-filosofskaya kontseptsiya fenomena uspekha [Socio-philosophical concept of the phenomenon of success]. Izvestiya Samarskogo nauchnogo tsentra Rossiyskoy akademii nauk, no. 14 (2-4), pp. 1072-1074 [in Russian].

Kuznetsov Ya. Ye. (2001) K voprosu o klassifikatsii faktorov uspeshnosti pedagogicheskogo protsessa [To the question of the classification of factors of the success of the pedagogical process] Paradigma. no. 1. Krasnoyarsk: SibGTU [in Russian].

Obama B. (2009, February 24). Address to Joint Session of Congress. Retrieved from: https:// www.whitehouse.gov/the-press-office/remarks-president-barack-obama-address-joint-sessioncongress

Perna L. W., \& Thomas, S. L. (2006) A framework for reducing the college success gap and promoting success for all. Washington, DC: National Postsecondary Education Cooperative.

Richnyy zvit Natsionalnoho ahentstva iz zabezpechennya yakosti vyshchoyi osvity za 2019 rik (2020) [Annual report of the National Agency for Quality Assurance in Higher Education for 2019]. Kyyiv: Natsionalne ahentstvo iz zabezpechennya yakosti vyshchoyi osvity [in Ukrainian]. Romanovskyy O. H. (2011) Pedahohika uspikhu: yiyi sutnist ta osnovni napryamy vyvchennya [Pedagogy of success: its essence and main directions of study]. Teoriya i praktyka upravlinnya sotsialnymy systemamy. no. 2 [in Ukrainian].

Ryff C. D. (2018) Well-being with soul: Science in pursuit of human potential. Perspectives on Psychological Science.

Shevchenko H. P. (2017) Dukhovna bezpeka: dukhovna kultura i dukhovni tcinnosti suchasnoi ludyny [Spiritual security: spiritual culture and spiritual values of modern person]. Dukhovnist osobystosti: metodologhiia, teoriia i praktyka, no. 3, pp. 361-373. Retrieved from: http://nbuv.gov.ua/UJRN/domtp_2017_3_32 [in Ukrainian].

Sidorchuk N.G., Dubasenyuk A.A. (2002) Professionalnaya pedagogicheskaya deyatelnost: sushchnost i sovremennyye podkhody [Professional pedagogical activity: essence and modern approaches]. Akmeologiya. no. 7. SPb: Sankt-Peterburgskaya Akmeologicheskaya Akademiya [in Russian].

Undergraduate Retention and Graduation Rates (April 2020) Retrieved from: https://nces.ed.gov/ programs/coe/indicator_ctrasp

Wolff-Eisenberg, C.\& Braddlee. (2018) Amplifying student voices. Community college libraries and academic support for student success. Retrieved from: https://sr.ithaka.org/wp-content/ uploads /2018/08/SR_Report_Amplifying_Student_Voices_CCLASS-_08132018.pdf 